\title{
THE BALKAN AND BLACK SEA COOPERATION
}

\author{
Prof. Dr. Oral SANDER*
}

"If there is to be another war in Europe, it will be due to stupid a mistake in the Balkans" BISMARCK

\section{Introduction}

The Balkan region is strategically located at the intersection of the Gulf, Eastern Mediterranean, and Europe. Since the 19th century, when the stratigic interests of the major European powers clashed in the region, they have followed the famous motto: "who rules the Balkans from outside the Balkans has the power to threaten Europe to the West and Russia to the east". Today, there is an additional and important geographic fact which escapes the eye: when we talk about the eastern half of Europe, we frequently seem to forget that nine of the fifteen Central and Eastern European countries are situated in the Balkans. The Balkan security is an integral part of the European and Mediterranean security environment and the present ethnic conflicts have strengthened this assertion. The cases of ethnic minorities and territorial disputes pose critical new problems which affect security. "Indeed, the Balkans could emerge as a major stumbling bloc to the creation of a stable security order... The real threat to European security is likely to come not from the military confrontation in Central Europe - as in the pastbut from political instability in Southeastern Europe" (Larrabee, 90-91: 87).

In this transitionary period of pervasive instability, Balkan cooperation seems to be the only long-term measure (i) to create a stable security order, (ii) to prevent the Yugoslav crisis from extending into the neighbouring countries and (iii) to accomplish economic development which might have a chance of softening nationalist aberrations and creating political stability. Consequently, regional cooperation for peace and stability in the Balkans, and in its eastern elongation, the Black Sea region, is something that the entire European countries have to take very seriously. I also think that Turkey, as a

*Prefessor of Political History, Ankara University 
Mediterranean and Eurasian, as well as a Balkan country, would have a key role in the realization of such a cooperation.

\section{Why Cooperaton Efforts Failed}

In the past, many attempts for regional cooperation in the Balkans have failed due to reasons which might give us important clues for future efforts. First, the Balkans have always been a ground of conflict among the great powers of Europe. As the Ottoman Empire retreated from the Balkans, big powers struggled to gain position in East Europe and "Austria-Hungary stepped in with major aspirations regarding the entire region. It met with resistance from Russia which had a strong political influence" in the Balkans (Ostojic, 1988: 3). The tensions that have kept the Baikans in turmoil were related to "problems caused by nonMediterranean powers and directly linked to those powers' pursuit of their own geopolitical objectives in the Mediterranean and the Balkans" (Varvitsiotes, 1992: 26). Consequently, in proved to be very difficult for the regional countries to come together as the peninsula became a scene of big power politics.

Secondly, the Balkan states, pressed together in a relatively small area, had been unable to form a defensive bloc and create mutual understanding among themselves. A number of geographical, historical, ethnic and religions causes had brought about enmities, territorial conflicts and finally the fragmentation of the Peninsula. The Balkan mountains, although not serving as a natural barrier to the invaders from outside the region, had actually separated peoples and pervented communication among them. This lack of communication had generated strong ethnic nationalism which, in turn, aggravated regional conflicts.

Thirdly, due to lack of popular participation in politics, the Balkan counties were ruled by autocratic and sometimes fascist regimes. These regimes had found it convenient to appeal to the nationalistic fervour of the masses by following policies of aggrandizement at the expense of their regional neighbours, often in alliance with cxtraregional big powers. A combination of all these factors, had turned the Balkans into the "powder keg" of Europe and resulted in political and economic marginalization and isolation of the peninsula from the rest of Europe.

This state of affairs have changed very little in the Balkans with the onset of bloc politics after World War II. The strategic interests of the big powers (this time the two super powers) still clashed and the region was divided into two antagonistic and solid blocs. The legacy of the Cold War was relative stability of the Balkans due to Moscow and Washington-held controls and the further economic, political and sociological isolation and marginalization of the: region.

\section{Contradictory Developments of Today}

Unprecedented changes in Europe since the mid-eighties have augmented detente by putting an end to the division of the continent into two antagonistic blocs. At the same time, these changes instigated new instabilities and conflict as well as rekindling historical enmities. Today, we witness two simultaneous and somewhat contradictory developments, one which encourages and the other that discourages 
regional cooperation. On the encouraging side, the regional states have freed themselves from the "straight jacket". of confronting alliances and communist regimes. With the disappearance of confronting blocs and the ideological division of the continent, it may now be possible to embark upon multilateral cooperation on a pluralist and more clearly identifiable web of relationships.

The collapse of antagonistic power blocs has also made the Balkans and the Black Sea peripheral to the strategic interests of the major world powers. In the atmosphere of detente, external actors seem less enthusiastic to intervene directly and have very litule desire to engage in a struggle by proxy in the Balkans (Mango, 1960: 46). This, of course, does not mean that conflicts inside the region will be reduced. On the contrary, the eruption of nationalistic feryour has turned the Balkans into a "boiling kettle".

The disappearance of military blocs, the fall of communist ideology in the continent and the onset of liberal economics and political democracy have also tightly tied the Balkans and the Black Sea region to Western Europe. These are important changes that could increase both the chances of regional cooperation and the fature extension of European integration efforts to the geographical borders of the continent. The democratization of the former communist states would also enable popular participation in government and thus the rising expectations of the masses would put an end to the artificial isolation of two regions from the rest of Europe. When compared with those of the Cold War, the consequences of all these unprecedented changes are both different and quite paradoxical: relative instability, as well as political and economic "togetherness" with Western Europe.

The fundamental source of instability and the discouraging development for cooperation in the Balkans and East Europe is rising nationalism on a religious and ethnic basis. It is a foregone conclusion that nationalist aberration, anywhere in the world, carries with it the dangerous possibilities of growing particularism and even military conflict. This is more so in the eastem half of Europe which today experiences the instabilities of a transitional period between bi-polar and multi-polar systems. Stephen Larrabee explains this phenomenon succinctly in a recent article: "Nationalism has always been a strong force in the Balkans, and the collapse of communist rule has given it even more potency. Nationalism has come to fill the political and ideological void left by the erosion of communism (Larrabee, 1992: 36). Harvey Feldman likens the Cold War years in the Balkans to a "freezer" and adds". "... the doors of the freezer has been torn away, and the politics and attitudes of the pre-1945 years lie thawing in the sun. Many give off a revolting smell" (Feldman, 1992:21). Furthermore, today, Eastem European nationalism rests more on the fceling of animosity towards "foreigners" rather than on commonly shared cultural values. This version of nationalism creates fear, suspicion and animosity among the Balkan peoples and the principle of "one nation, one state" now poses the danger of political re-mapping of Europe as if we have journeyed back to the end of World War I in a "time-machine".

While not remaining oblivious to the dangers inherent in nationalist upsurge and of the potency of the above analyses, rising nationalism in the region may also be seen, from a historical viewpoint, in an all too familiar pattern. Through ceniuries, Western European nationalism had led to mature expressions of self-ideniification through accumulation of wealth within the nation-state. This fulfilled nationalism, in tum, made 
them aware of their regional identity and the their broader cultural heritage. This long historical process is succinctly expressed by Andrew Mango: "It is precisely because Western Europe had such a long experience of nation-states and of the destructive potential of purely national allegiances, that a commitment to European Community has developed" (Mango, 1988: 9). As indicated elsewhere, the free expression of this national sentiment and accumulation of wealth within nation-states have been denied to the peoples of the Balkans and of the former Soviet Union until very recendly: "Poeples who were left behind or left out of the late 19th and early 20th century heyday of nationalism and the nation-state may now renew their quest for national fulfillment" (Fuller: 1990:65). This historical sequence of nationalism and nation-state $\rightarrow$ economic growth $\rightarrow$ regional consciousness $\rightarrow$ regional cooperation $\rightarrow$ integration has not been fully witnessed in the Balkans. What is now seen is the beginning of a similar trend within a different intermational setting.

Once the free expression of national sentiment is considered as a historical starting-point, the best chance of perventing its aberration and attaining aggressive forms lies in facilitating the second historical step: economic development and political maturity through regional economic and political cooperation in order to attain a common Balkan understanding. Direct interference from outside the region would only extend the period of instability and prove to be counter-productive as was the case before 1989. If nationalist aberrations and conflicts are to be controlled or softened for regional stability, 'the propor approach is again to facilitate regional cooperation. Today, free from the disruptive effects of the Cold War and from the multifaceted pressures of the Washington-Moscow axis, such efforts have the chance of acting as a "cushion" against national aberrations and conflicts by creating a sentiment of regional understanding on top of national identity. Such efforts are also in accord with the "global trend of intensifying communication and economic integration" (Rustow, 1991: 79).

Religion, as an expression of national identity in the Balkans proves today to be a disruptive element for peace ancl stability. Some observers foresee a slow but steadly division of the European continent on historical lines between Rome and the Byzantium, and between Austria-Hungary and the Ottomans. We also witness in the press a further schism between Turkey, Bosnia, Macedonia and Albania, on the one hand, and Greece, Serbia, Romania and Bulgaria, on the other, with stronger religious overtones of Islam and Christianity. Some politicians and observers go a step forward and see a "Muslim threat" in the "predominantly Christian Balkans." Mr. Radavan Karadzic, the Serbian leader in Bosnia, said: "The Muslims are getting more and more fundamentalist, and even a small Muslim entity is going to be a headache for Europe. (Fundamentalism) is crawling westward through the Balkans via Turkey, Kosova, and Macadonia... If the West decides to recognize Macedonia's independence there will be war there, too. So in a way the EC can thank Greece for objecting to the name Macedonia, and blocking recognition... If the Muslims rise up in Kosova they'll be crushed in 10 days... The Balkans is not like the US or Switzerland. It is a melting pot that never melted, despite a succession of foreign occupiers, Ottomans, Austro-Hungarians, Nazis or Tito's communists. So its wrong to talk about ethnic conflict, in the first place. Its a 
religious and cultural problem" (International Herald Tribune, 19 Oct. 1992: 2).

Such an viewpoint which seems to be shared in general by certain Balkan politicians and observers (see, for example, Varvitsiotes, 1992: 29) is a dangerous one. First, to evaluate the situation through the prism of a Christian/Muslim confrontation wiuld only serve to exacerbate instability in the Balkans. Secondly, to name Turkey, among fundamentalist countries is a mistake if we take into account the secular character of Turkey. Its foreign policy has never been shaped by or conducted with a view of religion. Thirdly, the Balkan Muslims are not Islamic fundamentalists. It is only natural that the crusade for "ethnic cleansing" in Bosnia and policies of aggrandizement or "ein folk, ein reich" on the part of some Balkan countries have led the Muslim minorities to emphasize their religious identities: "Serbian militiamen led by Radovan Karadzic, with their crusade for 'ethnic cleansing', have done much to create the current religious polarization by tearing apart communities where people of different faiths had long lived peacefully. Previously a highly secular group, the sort where mixed marriages and consumption of alcohol were not unusual, these Muslim Slavs, said one U.S. official, "have inevitably been turning to whomever will give them guns for survival" (Cohen, 1992: 2). Fourthly, the Bosnian Muslims' "commencement towards the process of independence" did not originate from religious considerations and not even from a desire to acquire a hasty and premature statehood. "Bosnian leaders pleaded with Western capitals to withhold recognition of Slovenia and Croatia, fearing that if it was granted Serbs and Croats would instantly fall upon Bosnia... (such an action) would oblige them to seek independence, too, and that, in turn, would provoke Serbia. Their safety, they said, lay in being part of a multi-national state" (Newhouse, 1992: 63). Thus, after the recognition of Slovenia and Croatia, BosniaHercegovina had no other choice but declare its independence.

Europe can have a definitive say on the new developments and ensure peace and stability in the continent only on the basis of an enlarged concept of Europe, which includes thoses regions considered as its geo-political extensions, i.e. the Balkans and the Black Sea. It has to extend to its natural borders if the old continent, on its road towards a new "architecture", is to claim its historic role as a power center in the world system.

\section{New Prospects}

Only five years ago, in 1988, the prospects for peace and cooperation in the Balkans looked bright. For the first time in history, Foreign Ministers of all Balkan countries met in Belgrade and issued a final communique on 26 February which underlined the necessity "to strengthen comprehensive multilateral cooperation in the region and in the spirit of promoting mutual respect, understanding and confidence the ministers stressed the interest and readiness of their countries to contribute to the enhancement of cooperation among the Balkan countries" The meeting was a significant contribution "to the relaxation of tensions and to the creation of a friendly atmosphere and dialogue in the Balkans, which also serves peace and security in the region, Europe and the world". It was also stated that "national minorities in the Balkan countries on whose 
territories they exist should be a factor of cohesion, stability, friendly relations and co-operation"1. We witness the same optimistic atmosphere in the following Sofia (1989) and Tirana (1990) meetings of the Balkan Foreign Ministers where the decisions were reiterated.

The Yugoslav crisis has, I think temporarily, put an end to this optimism about peace, stability and multilateral cooperation in the region. The conflict and the further danger of its spread to the other parts of the peninsula should not, however, lead us to overlook the significance of the fundamental historical patterns that could have a more important bearing on the future developments of the region. Pessimism emanating from the delimiting prism of today's events should be dissipated by an understanding of the underlying patterns of "yester-morrow" and proper and wise action of today.

Previous attempts at Balkin cooperaton have failed because they were based on short-term military interests of the big powers as well as regional states and thus no Balkan understanding beyond military cooperation evolved in the region. The Balkan Entente of 1934, it has to be remembered, was not even foreseen as an instrument of solidarity against Hitlerite Germany. Furthermore, nearly all Balkan groupings were the extensions of big power politics (especially in the strategic interests of England and the USA) and were not the spontaneous outcomes of a conscious regional cooperation. In order to succeed and thus create peace and stability in the Balkans, which is a must for both Europe and the Mediterranean, multilateral cooperation has to be based on the following premises:

(i) It has to include all Balkan countries regardless of the nature of relations between some of them. It has to be noted that until very recently all cooperation efforts had excluded at least some of the regional countries and failed mainly due to this reason. The Balkan Entente of 1934 had not exhausted all the possibilities of including Bulgaria and Albania, and experienced the first blow when Yugoslavia closed ranks with Bulgaria.

(ii) The future Balkan cooperation should not be directed against any regional or non-regional power. There is no long-term enmity and perception of threat in the international system, especially in an era of augmented detente. Military alliances cease to exist once conditions which give rise to cooperation change and states almost always feel insecure and are forced to initiate new formations and thus the region becomes divided on military lines. Slobodan Milosevic's proposal at the London Conference of August, 1992, for the creation of a "Balkan Confederation" consisting of Serbia, Macedonia, Montenegro, Romania and Greece is a course of action which should never be taken on the road towards a Balkan understanding.

As a consequence of these considerations, Balkan cooperation should be directed towards the goals of political understanding, economic cooperation, and culcural exchange and should encompass its immediate hinterlands of the Black Sea and even Eastern Mediterranean. As already noted, the potential for Balkan cooperation has been worked on recently by the Balkan Foreign Ministers. Although nothing concrete has been accomplished due largely to the Yugoslav crisis, the mere fact that they have been held

${ }^{1}$ For the full text, see: Reivew of International Affairs (Belgrade), March 5, 1988: pp. 32-3: 
with the participation of all Balkan cuntries is significant in itself and show the fundamental desire for the creation of a common Balkan understanding in time of European detente and regional integration efforts.

It goes without saying that the deepening crisis in Yugoslavia has hindered the pace towards a Balkan cooperation and a "solution" has to be found before an all-inclusive initiative is taken. This is not to suggest that all ills and wrongdoings are instantly curable and that an ideal magic formula can be found and worked upon. But the crisis has somewhat paradoxically demonstrated the necessity and even urgency of the creation of a regional "device" to handle the present problem or any future ones. If there were some kind of a "Balkan Council" before the crisis flared up, the break-up of Yugoslavia would not have attained its present proportions. Within such an institution, the voices of all regional parties could have been heard without the infiltration of non-regional interests which had always fallen short of meeting regional requirements. Once the problem attained its present intensity, there was no international mechanism for dealing with the conflict.

Seeing that the present international organizations have failed to stop the conflict, an observer proposes in desperation: "A dedicated, multiyear program that teaches skills in the management and resolution of ethnic conflict throughout Central and Eastern Europe is an urgent need, but more is the pity that it seems to exist nowhere on the agenda of the United Nations or the European Community" (Feldman, 1992: 25). I think it is very difficult if not impossible to teach the peoples of any region the skills to resolve their ethnic conflicts from outside. The only safe and long-term solution lies in what and how they learn from history and solve their differences within regional institutions before they get out of control. Regardless of how the Yugoslav crisis unfolds or ends, it is now time to embark upon a process of regional cooperation in the Balkans leading to such an institution which could act in time to prevent its extension to the neighboring peoples in the Balkans and deal with future crises that might occur.

\section{Turkey's Role in the Balkans and the Black Sea Economic Cooperation}

A recent development which could open new prospects for peace and stability in the Balkans is the Black Sea Economic Cooperation (BSEC) which is established in 1992 on the eastem elongation of the Balkans and the geo-political extension of Europe from the Balkans to the Caucasus. It is foreseen that BSEC would ultimately unify the economic and cultural potentials of and augment political cooperation in the Black Sea littoral including the Balkans and the Caucasus. It is also stated that BSEC would not be an altemative to the E.C., but would function as its component part. Thus, BSEC is designed to be a European organization linking the member states more firmly and under stable conditions to the emerging European integration, rather than dividing the continent into new and exclusive compartments.

The BSEC has to be evaluated within Turkey's regional cooperation initiatives such as the CSCMED and the Middle East Economics Region and its desire to bolster bilateral ties with the nations to the north and south. Turkey is cognizant of the fact, however, that its future will be determined primarily by developments in Europe and that the stability of the interlocking subregions surrounding Turkey (the Balkans, the 
Caucasus and Eastern Mediterranean) are most likely to be assured by an effective system of European institutions, like B.SEC, which can emanete beyond Europe's physical borders (Stuart, 1991:1).

The BSEC has been criticized on the grounds that the regions it intends to develop and unify are technologically not very advanced, face economic retardation and most importantly lack capital accumulation. Although these views seem convincing, it has to be remembered that in the past it proved to be very difficult to enhance economic cooperation among the countries surrounding the Black Sea because of the artificial political and military barriers which existed in the Cold War years. Today, however, the existing situation and expectations are quite different since Moscow and Ankara are not rivals but partners in the Black Sea cooparation.

In addition, it is possible to observe econoic complimentarity between Turkey on the one hand, and the former Soviet republics and Balkan countries on the other. Russia's selling of natural gas and possibly oil and the construction in Turkey of large industrial plants; Turkey's readiness to sell all kinds of consumer goods; close cooperation in the field of tourism may be given as important exambles. "The existing level of Turkey's manufacturing industry is sufficient to enable her to export to these countries, to operate existing establishments and build and operate new ones in the fields of management, monetary transformation and privatization, the Turkish private and public sectors are able to guide and orientate the economic activities of those countries" (Manisali, 1991: 48; Halefoglu, 1991: 78). The regions that BSEC will try to unify are potentially rich but mainly due to mismanaged economies they have not fully cploited existing resources. If the member countries are capablc of forming a market of at least 200 million people, then there is great likeliood that the necessary capital will flow in and the region's tourism potential will help the process. "Indeed, if the Black Sea Zone takes off, Turkey could emerge as an important economic power in the Balkans in the next decade" (Larrabee, 1992: 42).

Technically, BSEC is an initiative for a gradual effort toward the free circulation of capital, services, goods and labour. Its economic aims are as follows: (i) To revitalize the Black Sea littoral and its hinterlands which had so long been marginalized in the global economic activity and lost its economic balance. (ii) The transfer of the Turkish experience in free market economy to the state-controlled economies of the Caucasion, Balkan and Central Asian countries and exchange of information regarding banking and investment planning. (iii) The rational exploitation of existing opportunities regarding tourism, fishing and transportation through joint programmes and ventures.

The political aims of BSEC may be summerized as follows: (i) To take advantage of the new international conjecture created by the European detente. (ii) To strengthen political understanding and cooperation after realizing the necessary economic infrastructure. (iii) To facilitate the active participation of the member countries in the integration process in Europe through regional cooperation. The summit Declaration on Black Sea Economic Cooperation, which was signed by the 
heads of state or government of all the member countries ${ }^{2}$ in Istanbul on June 25,1992 , makes it very clear that BSEC intends to be a European organization and an integral part of the evolving European architecture.

The political aspects of cooperation is also stated in the Bosphorus Statement which the members issued at the end of the Istanbul meeting in 1992. They noted that partnership between them was inspired by the values of democracy, rule of law and respect for human rights and emphasized cooperation and dialoque in mutual relations. They were realistic enough to acknowledge the existence of serious conflicts and the danger of new tensions to arise and emphasized the need for the peaceful settlement of all disputes by the means in accordance with the principles set out in the CSCE documents to which they all subscribed.

The complexity of the Balkan crisis forces Turkey to follow a more active, independent and balanced foreign policy in the Balkans. Within the present atmosphere of instability, although there is a great need for improved bilateral relations, there are still hopes for a novel re-structuring in the Balkans on multilateral cooperation in the fields of politics and economy like the BSEC. Without such endeavours, it would be very difficult, if not impossible, to expect long-term peace and stability to settle in the peninsula. Turkey is the most likely candidate to embark upon such a course of restructuring in the Balkans.

\section{Conclusion}

To initiate and support multilateral cooperation in the Balkans and the Black Sea region, which together compise the southeastern elongation of the European continent, has to be seen as the first and correct step towards the stabilization of the post-Cold War era. The unhappy fact that most important conflicts of the era exist in this part of Europe should not be considered as a paradox but as a historical outcome of the different and still differing version of nationalism in the western and eastern parts of Europe and also as an added reason to emphasize the urgency of regional cooperation towards a continental identity. The success of regional cooperation will have the best chance of combatting nationalist aberrations and conflicts. Furthermore, if Europe is to attain peace and stability after the termination of the relative security and clear-cut delimitations or controls of the bi-polar world system, it has to facilitate regional cooperation units on which the future European structure and stability will eventually be based. "(I)t is forums of cooperation... that might hold the best hope of a solution to the dangers posed by the wave of nationalism sweeping all the former Communist countries (Whitney, 1991: 1).

The Balkan cooperation and its component part, the BSEC initiative, form one such grouping in a troubled region worthy of support. It has to be noted that the end of the Cold War divisions have also narrowed down the "great divide" between the western and eastem parts of Europe and thus tied the latter's social, economic and political future to those of the former. Consequently, the democratization and liberalization of regional politics and economy within regional cooperation units is the surest and long-term 2The member countries are: Turkey, Greece, Albania, Bulgaria, Romania, Moldava, the
Ukraine, the Russian Federation, Georgia, Armenia, and Azerbaijan. 
guarantee of European peace and stability. The Balkans und the Black Sea region need no longer be cut from the developments of Western Europe, as observed by an expert on the region four years ago: "(T)he Balkan countries were seriously lagging behind both the integrational and other economic processes triggered of and stimulated by the scientific-technological revolution, and the trend of easing international tensions initiated by the two superpowers' negotiating contacts and reflected in efforts to seek negotiated solutions to disputed issues in various parts of the world (Petkovic, 1988: 1).

An expert on the region is to the point when he observes that "the Western European powers have an interest in avoiding anyone's dominance of the Balkans which would inean an implicit challenge for control of the Bosphorus, Eastern Mediterranean and adjacent areas... Their interest now will be to ensure a balance in the region and to avoid an inviting vacuum into which forces hostile to European security might be tempted". From the 19th century up to the end of the Cold War this force was Russia and the Soviet Union. But today, "the region's role as a 'buffer' vis-a-vis Islamic fundamentalism and/or radical Arab nationalism is seen by some Western and Central Europeans as one of increasing importance" (Nelson, 1991: 122). Thus, it is only logical to consider Turkey as a secular "buffer" which separates the Middle East from the Balkans and an agent of moderation in the region's religious divisions.

As to the conflict in former Yugoslavia, there is no definite, clear-cut and quick solution apart from massive military intervention which the big powers decline to undertake. U.N. and E.C. intervention short of such an undertaking will not prove to have positive effects if we take into account the extremely complex political and strategic nature of the conflict. "Europe's best strategy for dealing with future issues of security (broadly defined) on its peripheries is to contribute to the processes of conflict resolution and economic modernization in these subregions" (Stuart, 1991: 10). With the loss of the familiar Soviet enemy, democratic politicy on both sides of the Atlantic has lost its vision and its decisiveness. The inability of European democracy to prevent civil war in former Yugosiavia gave a clear signal to all nondemocratic political leaders that ultimatums pay much more than negatiations. The simultaneous failure of WE leaders to explain persuasively to their voters the need for historically new levels of cooperation in Europe merely strengthens nondemocratic tendencies elsewhere ... In the heart of Europe, few seem to recognize the advence of anti-democracy. Elsewhere, few care (Urban, 1992: 5).

This "treatment" of the subject can be epitomized by the following succinct and all-inclusive observation: "No political subject in the Balkans can remain indifferent to whether the region will be included in the new course of history or stay behind to languish like a province on the margins of great events. Ergo the urgency of forming a new Balkan consciousness which will rise above divisions, local hegemonisms, greater state policies, narrow nationalisms and similar phenomena that belong to the ideological and political arsenal of the 19 th century... Many of the new problems facing the Balkan countries can be resolved through joint endeavor" (Ostojic, 1988: 5). In the long run, we have no other choice. 


\section{REFERENCES}

Roger COHEN (1992), "Ancient Religious Feuds, Once Subdued, Fuel War in Bosnia", International Herald Tribune, 18 Sep. 1992.

Harvey J. FELDMAN (1992). "The Balkan Dimensions of the Yugoslav Crisis", Mediterranean Quarterly, Summer, 1992.

Graham E. FULLER (1990), "The Emergence of Central Asia", Foreign Policy, Spring, 1990.

Vahit HALEFOGLU (1991), "The Importance of the Soviet Union for Turkey", Turkey's Relations with the Soviet Union and Eastern Europe (International Girne Conferences), Middle East Business and Banking Magazine Pub. (BEBBM), Istanbul, 1991.

Stephan M. HORAK (1985), Eastern European National Minorities, 19191980: A Handbook, Littleton, Colorado: Libraries Unlimited, Inc.

Stephan F. LARRABEE (1990-91), "Long Memories and Short Fuses", Change and Instability in the Balkans", International Security, Winter, 1990-91.

No 2 (Summer 1992).

Andrew MANGO (1988), "Turkey's Vocation", Turkey's Place in Europe (Ed. Erol Manisal1), MEBBM Pub., Istanbul, 1988.

Erol MANISALI (1991), "A New Dimension in Turkey's Relations with the North and the Northeast", Turkey's Relations with the Soviet Union and Eastern Europe (Intemational Gime Conferences), MEBMM Pub. Istanbul, 1991.

Daniel N. NELSON (1991), Balkan Imbroglio: Politics and Security in Southeastern Europe, Westview Press, 1991.

John NEWHOUSE (1992), "The Diplomatic Round; Dodging the Problem", The New Yorker, August 24, 1992.

Mirko OSTOJIC (1988), "The Balkans in the Eighties" Review of International Affairs (Belgrade), March 5, 1988.

Ranko PETROVIC (1988), "Confronting the Future", Review of International Affairs (Belgrade), March 5, 1988.

Stephen S. ROSENFELD (1992), "Serbs Are the Problem and Minority Rights the Solution", International Herald Tribune, Sep. 29-27, 1992. 
Dunkwart RUSTOW (1991), "Democracy: A Global Revolution?", Foreign Affairs, Spring, 1991.

Douglas T. STUART (1991), "Redefining Turkey's Role in European Security", Manuscript: a Presentation at a Conference Sponsored by Boğaziçi University, Istanbul, No. 21-22, 1991.

Jan URBAN (1992), "Central Europe: The Dark View Comes into Focus", International Herald Tribune, 13 Oct. 1992.

Ionnis M. VARVITSIOTES (1992), "Security in the Mediterranean and the Balkans", Mediterranean Quarterly, Summer, 1992.

Craig R. WHITNEY (1992), "Europeans Push for Joint Curbs on Nationalism", International Herald Tribune, Jan. 27, 1992. 